\title{
Correction to: Hemolytic uremic syndrome caused by sea anemone sting: a case report
}

A. Young Kim ${ }^{1}$, Kyu Hyang Cho ${ }^{1 *}$, Seok Hui Kang ${ }^{1}$, Jong Won Park ${ }^{1}$, Jun Young Do ${ }^{1}$ and Min Kyoung Kim ${ }^{2}$

Correction to: BMC Nephrol (2021) 22:14

https://doi.org/10.1186/s12882-020-02218-5

Following publication of the original article [1], the authors identified an error in the affiliation of author Jun Young Do and author Min Kyoung Kim.

The affiliations have been updated above and the original article has been corrected.

\section{Author details}

'Division of Nephrology, Department of Internal Medicine, Yeungnam University College of Medicine, 170 Hyeonchung-ro, Nam-gu, 42415 Daegu, Republic of Korea. ${ }^{2}$ Division of Hemato-Oncology, Department of Internal Medicine, Yeungnam University College of Medicine, Daegu, Korea.

Published online: 07 July 2021

\section{Reference}

1. Kim AY, et al. Hemolytic uremic syndrome caused by sea anemone sting: a case report. BMC Nephrol. 2021;22:14 https://doi.org/10.1186/s12882-02002218-5.

* Correspondence: chokh@yu.ac.kr

'Division of Nephrology, Department of Internal Medicine, Yeungnam

University College of Medicine, 170 Hyeonchung-ro, Nam-gu, 42415 Daegu, Republic of Korea

Full list of author information is available at the end of the article

(c) The Author(s). 2021 Open Access This article is licensed under a Creative Commons Attribution 4.0 International License, which permits use, sharing, adaptation, distribution and reproduction in any medium or format, as long as you give appropriate credit to the original author(s) and the source, provide a link to the Creative Commons licence, and indicate if changes were made. The images or other third party material in this article are included in the article's Creative Commons licence, unless indicated otherwise in a credit line to the material. If material is not included in the article's Creative Commons licence and your intended use is not permitted by statutory regulation or exceeds the permitted use, you will need to obtain permission directly from the copyright holder. To view a copy of this licence, visit http://creativecommons.org/licenses/by/4.0/ The Creative Commons Public Domain Dedication waiver (http://creativecommons.org/publicdomain/zero/1.0/) applies to the data made available in this article, unless otherwise stated in a credit line to the data. 